\title{
Beyond the Classroom Wall: Community Engagement Instruction
}

\author{
Jenny Wang ${ }^{1, *}$, Shu-Chuan Lai ${ }^{2}, \&$ Chao-Min Wang ${ }^{3}$ \\ ${ }^{1}$ Department of Foreign Languages, National Formosa University, Taiwan \\ ${ }^{2}$ Department of Early Childhood Educare, Chung Chou University of Science and Technology, Taiwan \\ ${ }^{3}$ Department of Early Childhood Education, Toko University, Taiwan \\ *Correspondence: Department of Foreign Languages, National Formosa University, Taiwan. Tel: 886-5-631-5820. \\ E-mail: wang170@yahoo.com
}

Received: October 22, 2016

Accepted: November 3, $2016 \quad$ Online Published: November 25, 2016

doi:10.5430/wje.v6n6p31

URL: http://dx.doi.org/10.5430/wje.v6n6p31

\begin{abstract}
This study $(\mathrm{n}=11)$ examined active community-school collaborative classes using sociocultural constructivist approaches over an academic year in an early childhood institute. A semi-formal interview was conducted to describing how the early childhood teachers and community members worked collaboratively to develop community engagement activities in a constructivist manner for an early childhood instruction. The guiding research questions sought to explore both teachers and community members' perspectives regarding integrating community activities within the early childhood curriculum. Results from the qualitative data of perspectives of past experiences, collaboration between the school and its community, interaction with the school teachers/community officials, and attitudes toward into collaborative community/school activities, were examined and analyzed based on grounded theory. Both school and community emphasized school-community collaborative engagement to enhance and extend existing classroom practice. Findings suggest teachers' positive teaching impacts resulted from involvement, instant feedback, and productive teaching resources with the community engagement. Findings also suggest community's positive impacts resulted from active engagement, community-school relationship, and contribution in community activities. By providing collaborative community engagement activities and embedding community contribution in instruction, young children may be better to maximize their learning development and optimize their levels of competency. Activities for community integration in the early childhood learning are discussed.
\end{abstract}

Keywords: community engagement; collaboration; social constructivist

\section{Introduction}

A proverb "It takes a whole village to raise a child" is well known from the past. It is certainly true that child upbringing is a communal effort. The fundamental meaning is to emphasize on the values of community, unity, cooperation, and sharing. Applying it into current childhood education, it is indeed proclaiming the necessity for classroom-community connection to promote learning in a wider community beyond the classroom wall. The curriculum objectives for young children in early childhood institutes should include experiences that stimulate every aspect of children's development-social, physical, and emotional development. All children can definitely benefit more when the wider community gets involved, such as the extended family, neighbors, and friends. They therefore receive new knowledge acquisition in neighborhood spaces. Teaching and learning can occur beyond the classroom, and in between classes. Teaching/Learning setting can be extended to a recreation or leisure setting. Therefore, location of instruction has become important components in curriculum design. Instruction of classroom-community collaborations shall be a portion of curriculum that occurs in the community. By their nature, children usually learn by exploring and discovering independently (Mallaguzzi, 1998). Implementing community engagement instruction is intended to ensure that all children experience the world around them, explore and collect the information, and gain new cognitive skills. It is to recognize that there are serious discrepancies between educators' planning for community engagement for their school and community/family connections (Shartrand, Weiss, Kreider, \& Lopez, 1997). 
Constructivism underlines the importance of an individual's knowledge, beliefs, and skills in the experience of learning, and defines the construction of new learning as a combination of preparedness for learning, existing knowledge, and new information of real-world experience (Airasian \& Walsh, 1997; D'Angelo, et al., 2009). Learning is a result of an activity and self-organization (Ozturk, 2016). Individuals construct knowledge and meaning from their own experiences. Constructivism is therefore thought to be a theory related to knowledge acquisition and explain how learning occurs (Fosnot, 2005). Social interaction among learners is a basic principle of social constructivism (Chen \& Bryer, 2012; Driver, Asoko, Leach, Mortimer, \& Scott, 1994; Kukla, 2000; Wang, 2014; Wells, 1999). Vygotsky $(1978,1981,1986)$ emphasizes the critical importance of the social contact that knowledge is a socially constructed entity. Specifically, engagement of the broader community in school encourages volunteers from all areas of life to engage in school activities. The school and community collaboration may therefore contribute a better learning achievement for students (Gestwicki, 2013; Goodland, 1984; Weller, Gallagher, \& McDonough, 1995). The importance of community involved in a meaningful school instruction has been advocated in the last two decades (Fullan, 1997). Sergiovanni (1994) and Tal (2001) also state that community is one of the key components that connects students and teachers together. Community involvement in school activities should be above and beyond the classroom instruction of social activities. Curriculum planners should establish meaningful connections with many different settings in the community where the children live. For instance, environmental education in particular is emphasized as being elevated by school-community partnership. Science also requires various levels of collaborations between classroom and science groups outside the school involving individual and social processes (Crawford, Krajcik, \& Marx, 1999) to promote student's scientific knowledge. In another hand, the community also gain benefits from participating the school activities. With the highly active involvement with the children, public community sectors identify and integrate resources and services to strength and advocate their programs. Indeed, they can be recognized by public and their resources can be accessed (Epstein, 2001).

\subsection{Purpose of Study}

The purposes of this study is to describe and analyze the proposed instruction of community engagement collaboration based on the sociocultural constructivist approach, which focuses on curricular activities, and to determine and discuss the perceptions of the main instructional approach of the early childhood education curriculum.

\section{Methods}

\subsection{Setting}

The school in this study is a preschool providing early childhood education programs for younger children between the ages of two and six, prior to the start of grade 1 as a compulsory education located in central Taiwan, with a population of about 125 students. Education system in Taiwan is bit different compared to western countries. Preschool education is not part of compulsory education system in Taiwan, including preschool playgroup (children ages 2-4), pre-K (children ages 4-5), and kindergarten (children ages 5-6 years). The school in this study declares its mission that school should serve the community together for children and community members by offering activities that celebrate diversity, creativity, and kindness. These values are embedded within a child-centered, school-community collaboration curriculum that provides children and community groups with opportunities themselves through meaningful activities. The school seeks for opportunities of community involvement and fits the basic principle of the sociocultural constructivist approach.

\subsection{Participants}

The participants in this study were early childhood teachers (6) and community members (5) who took part in various community engagement activities of major collaborative events. At the end of the school year, an interview was conducted to the participants. All of these teachers and community members participated on a voluntary basis. The participants also signed the consent form agreeing and understanding that all the information they provided would be used for the study purposes only. Table 1 presents demographic information about the participants. During the interview discussions, both note-taking and audio-recording discussions were used under the interviewee's permissions. Subject Teacher was coded to as $\mathrm{T}$ and community member was coded as $\mathrm{C}$, and different individual of teachers or community members were coded as the number followed by the code $\mathrm{T}$ or $\mathrm{C}$, such as $\mathrm{T} 1$ or $\mathrm{C} 1$. 
Table 1. Demographics Characteristics of Participants

\begin{tabular}{llllll}
\hline Name & Age & Gender & $\begin{array}{l}\text { Years of } \\
\text { working } \\
\text { experience }\end{array}$ & Affiliation & $\begin{array}{l}\text { Children's age group } \\
\text { (for teacher group } \\
\text { only) }\end{array}$ \\
\hline T1 & 26 & F & 5 & Seattle Preschool & $5-6$ \\
T2 & 28 & F & 3 & Seattle Preschool & $5-6$ \\
T3 & 22 & F & 7 & Seattle Preschool & $4-5$ \\
T4 & 24 & F & 4 & Seattle Preschool & $4-5$ \\
T5 & 26 & F & 6 & Seattle Preschool & $4-5$ \\
T6 & 31 & F & 4 & Seattle Preschool & $4-5$ \\
\hline Avg & 26.17 & & 4.83 & & NA \\
\hline C1 & 35 & M & 6 & Taiwan High Speed Rail, Taichung & NA \\
C2 & 33 & F & 4 & South District Office, Taichung City & NA \\
C3 & 42 & F & 8 & Taichung City Library & NA \\
C4 & 40 & M & 8 & National Policy Agency, Ministry of & \\
& & & & the Interior & NA \\
\hline C5 & 37 & F & 5 & Chunghwa Post Co. & \\
\hline Avg & 37.20 & & 6.20 & & \\
\hline
\end{tabular}

Note: $\mathrm{M}=$ Male; $\mathrm{F}=$ Female

\subsection{Collaboration Instruction: Community Engagement Activities}

This study focused on active engagement collaboration between the school and its community throughout an academic year. A list of appropriately eight categories of constructive engagement was created as shown in Table 2. In total, community engagement activities sustain 8 field trips, 1 Christmas celebrations, 1 Halloween trick or treat, 4 art crafts at local park, 2 flower festivals in both spring and fall seasons, 1 Chinese New Year lion dancing celebration, 8 environmental education projects, and 10 community open houses. The school's program sustains about eight field trip per academic year which relate to the sciences, arts, environments, and professions interdisciplinary school curriculum. Major holidays are also delighting for young children to celebrate for, such as Halloween and Chinese New Year. Happily, community residents could be able to be part of the events, observing or engaging the activities. Environmental education projects are the inclusive summary of the school-based curriculum. The projects incorporate the themes and the concepts of the in-class instructions. After that, the children have an opportunity to personally experience and sense what they have learned in the classroom immersing themselves in real world. Ideally, the children might have a concrete idea through the process of variety of community tours.

Managing this complex collaboration demands a major effort. Therefore, the school staff called for establishing different visits to public community open houses. Public community open houses here included city library, police station, fire station, post office, train station, high speed railway station, city hospital, and boro's office. The school staff conducted and communicated with all the representatives of different communities to ensure the plan and suggest activities. The main events were identified and outlined by the researchers along with the discussion with the school instruction planners. After that, the activities were then discussed and established during the school-community meetings with the community members. The community members in this study include public stakeholders, head of district office, and district office staff. The meetings took place 10 times through the year before the events. All the participants were involved in curricular decisions. On a few occasions, such as community open house and flower festival, the community members took an active part in conducting and guiding the actual activities with the school teachers and the students. The staff from public community sectors actually provided guidelines of the engagement activity and also actively interacted with the children during the activities, such as guiding the children to play the games, teaching the children how to fold the paper kite, touring the children around the office, and introducing the children every profession in the public office. 
Table 2. Types of Community Engagement

\begin{tabular}{lll}
\hline Type of Events & $\begin{array}{l}\text { Number of } \\
\text { Events }\end{array}$ & Collaborative Community Members \\
\hline Field trips & 8 & Business contact staff \\
Christmas celebration & 1 & District Office staff \\
Halloween trick or treat & 1 & Local office and business owners \\
Art craft at local park & 4 & District Office staff \\
Flower festival & 2 & City Office representative \\
New Year lion dancing celebration & 1 & Head of District, District Office staff \\
Environment projects & 8 & N/A \\
Community open house & 10 & Public community officials \\
(ex. library, police station) & & \\
\hline
\end{tabular}

\subsection{Instruments and Data Collection}

Aiming to determine the sociocultural constructivist learning views of preschool teachers and community members, this study is a qualitative research. The instrument used for this study contained open and semi-structured interviews with the preschool teachers (6) and community members (5) which took place at the end of the study for determining their perspectives of sociocultural constructivist approaches to children's impacts as shown in Figure 1. Each interview lasted about 10-20 minutes.

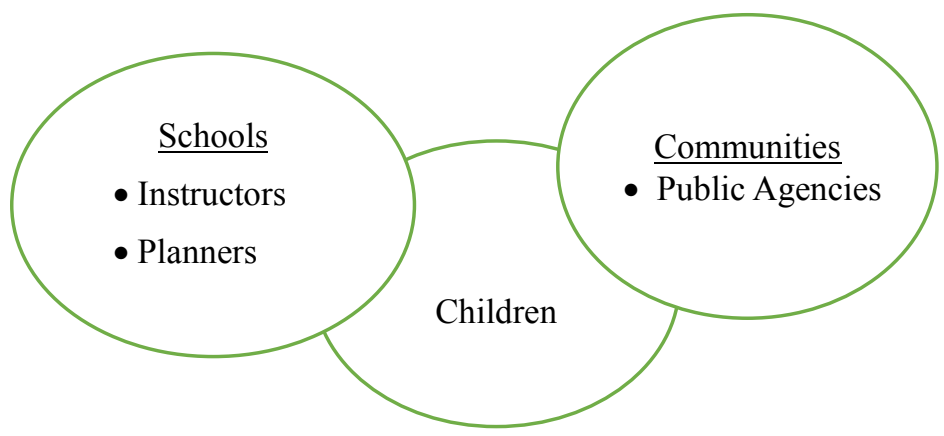

Figure 1. Structure of Data Collection

The aim of interview was to obtain deep, detailed, multi-version, and qualitative information about the pre-designed topic and participants' views, experiences, ideas, and emotions about specific topic (ASA, 1998). Therefore, this technique was conducted in this study to enable preschool teachers to reveal their views and experiences about implementing constructivist approach in a stress-free and interactive setting. It could also offer insights of activity development.

In addition to demographic questions, the interview question form had 2 open-ended and 1 closed-ended questions in total. Illustrative research questions were:

1) What do you like about the collaborative instruction of community engagement activities in your instruction/work?

2) What do you dislike about the collaborative instruction of community engagement activities in your instruction/work?

3) Do you agree to continue to implement this kind of community engagement activities into your future teaching/work?

The interview was used for describing the perspectives of community engagement activities. The interview was also 
to determine the relationships between the school and its school. The participants were asked to provide their personal experiences and perspectives of collaborative school-community activities.

\subsection{Data Analysis}

When participants were invited to provide comments for what they liked or disliked about the community engagement activities, they listed a wide range of comments and feedbacks as the qualitative data for this study. Audio recordings from interviews were transcribed and documented. The documents were checked against the notes kept during the interview sessions and detailed interview answers to each of the questions were obtained. The written format of interview answers were later submitted for the interviewees who participated in the study, and the transcripts were confirmed for their accuracy.

Grounded theory method was then conducted for coding the qualitative data. The key idea of this method is to discover a phenomenon by conceptualizing and categorizing the key elements of the phenomenon, and then generating a theoretical explanation of that phenomenon (Strauss and Corbin, 1998).

\section{Results}

After carefully read the transcribed and written answer forms several times, 111 different answers were scanned and coded for each question of aspects. Starting with the positive perspectives in community engagement activities between the school and its community, the answers were then categorized into different themes from the teachers (Figure 2) and community members (Figure 3). In the categorization process, the similar answers were sorted together and 9 categories formed for the positive aspects from the teachers and 7 from the community members. In the phenomenological process for the positive aspects, four themes emerged which interpreted by the researchers as: sociocultural view, involvement, feedback, and teaching productivity with the teachers; four themes emerged which were interpreted by the researchers as: engagement, community-school relationship, and contribution with the community members.

For the interview answers based on the negative aspects in community engagement activities between the school and its community, the answers were then categorized into different themes from the teachers' views (Figure 4) and community members' views (Figure 5). Interestedly, many short answers were provided when asked what they disliked about it. In the categorization process, the similar answers were sorted together and 5 categories formed from both the teachers and community members. In the phenomenological process for the negative aspects, two themes emerged which were interpreted by the researchers as: time consuming and safety with the teachers; two themes emerged which were interpreted by the researchers as: scheduling and communication with the community members.

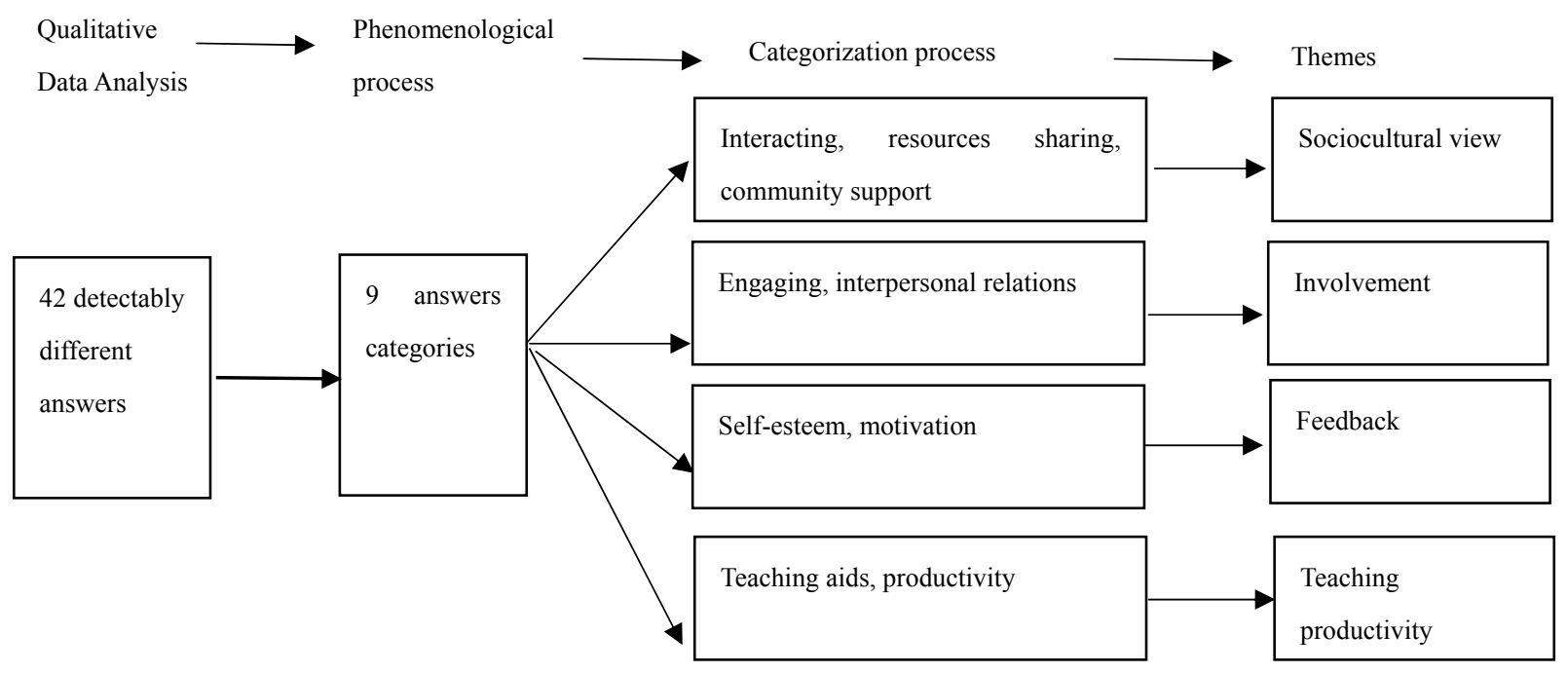

Figure 2. Diagram of the Ground Theory of Analysis for the Qualitative Data of the Positive Aspects from the Teachers 


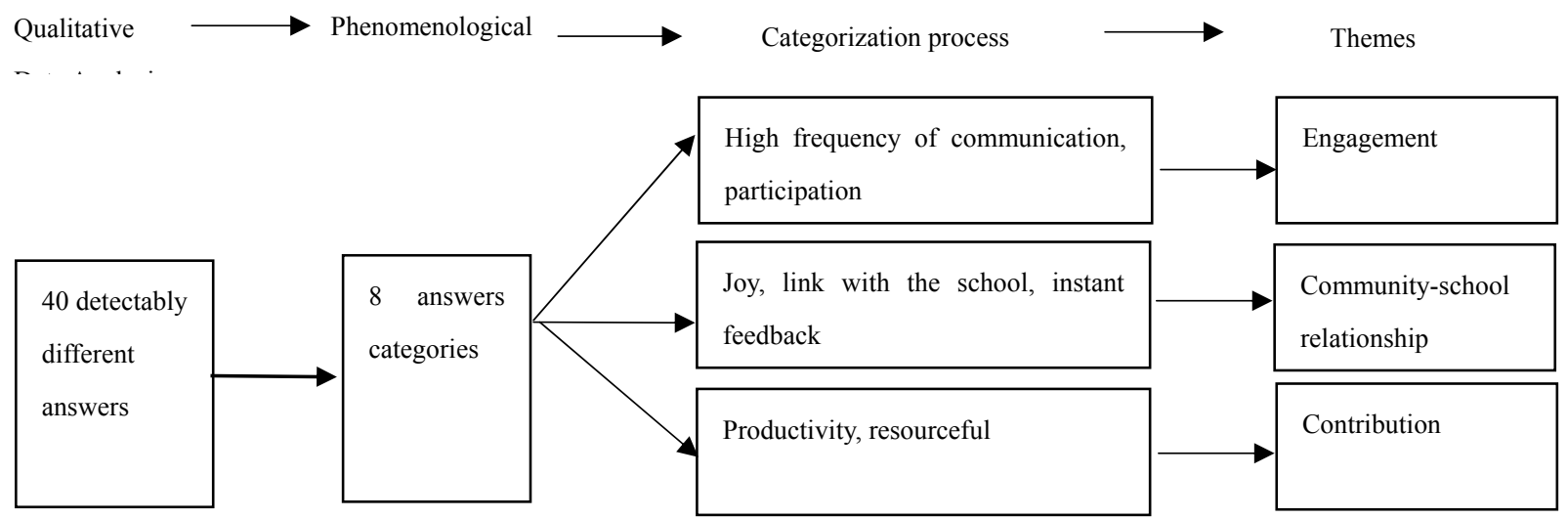

Figure 3. Diagram of the Ground Theory of Analysis for the Qualitative Data of the Positive Aspects from the Community Members

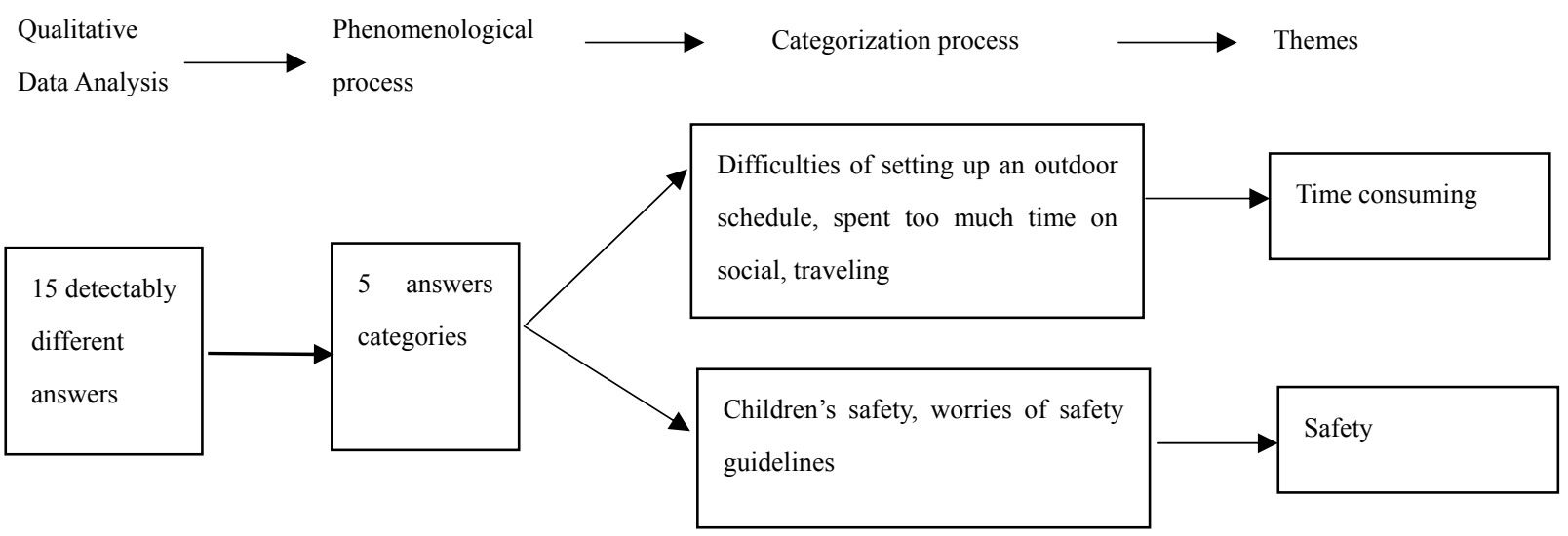

Figure 4. Diagram of the Ground Theory of Analysis for the Qualitative Data of the Negative Aspects from the Teachers
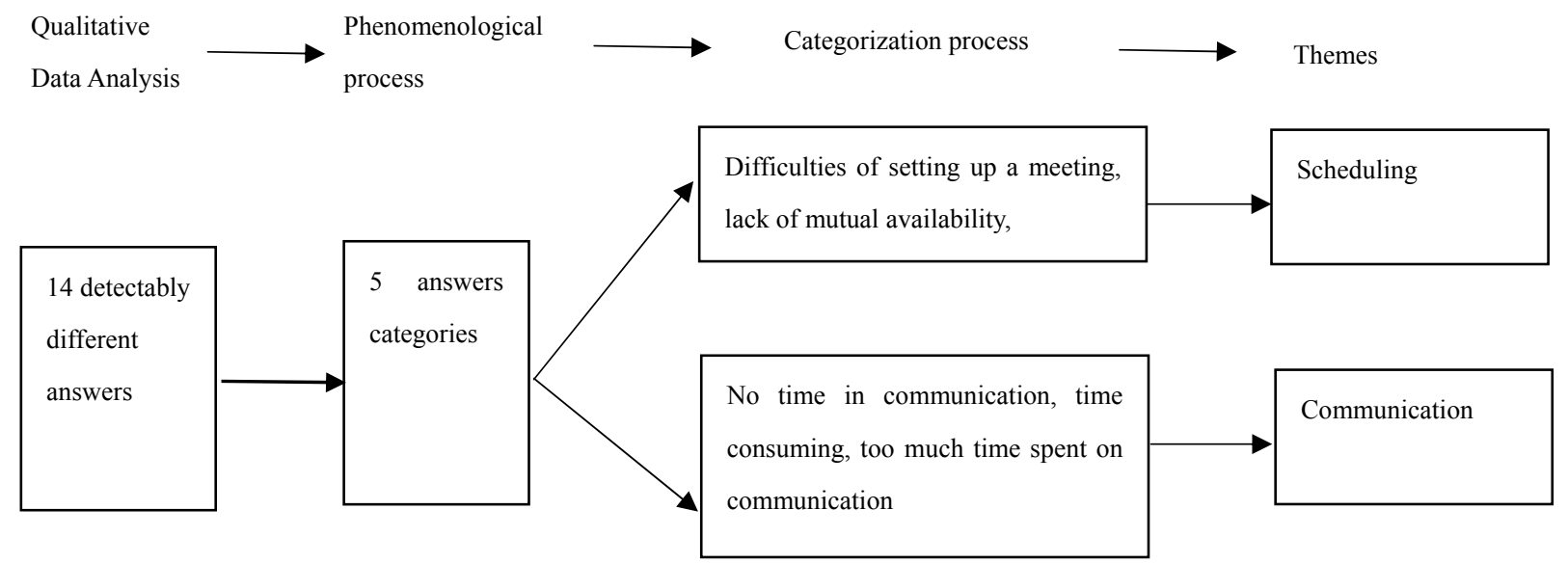

Figure 5. Diagram of the Ground Theory of Analysis for the Qualitative Data of the Negative Aspects from the Community Members 


\subsection{Research Question 1: Participants' Positive Attitudes toward Active Community Engagement Collaboration}

\subsubsection{Positive Connections from the Teachers}

In the qualitative section survey, when preschool teachers were asked about what they liked about the collaborative community engagement activities in the instructions, their comments included: (1) community support, (2) interaction between school and community, (3) powerful teaching resources, (4) deep involvement, (5) students' learning motivation, (5) clear teaching aids, (6) resources sharing, and (7) practical teaching and learning. Obviously, participants enjoyed merging community activities into their instructions, with experiences through the local community involvement. For example, T2 commented, "with the community support, I felt a bit easy when it came to the lesson plan"; T5 also stated, "I liked the field trip, I can actually show my students what the things are"; T6 reported, "it is exactly like a saying that it is better to travel far than to read voluminously". More importantly, many participants (T1, T3, T4, T6) reported that they felt great when they physically presented local resources to the students during the environmental projects of community tours. What students see in their real life can be referred directly what they have learned earlier in the class. In addition, enhancing students' learning interests and receiving students' joyful feedback were also positive teaching reinforcement they received. Interestedly, participants stated that through the community engagement activities, they could get to know their students better and build in a positive link with them. For example, T1 said "I've never imaging that my student so adored me. One of my students during the field trip in supermarket said he wanted to break his piggy bank to buyme some candies"; T4 mentioned, "having a private conversation with my students during the community tour is just so fun".

Community resources provide immediacy and hand-on teaching aids. Teachers appreciated for the hand-on resources they have to implement into their teaching materials. T1 and 3 others delivered their gratefulness to their community members for bringing resources into the school instructions. In addition, community activities have given children opportunities for physically exploring their communities around. Through the community activities, teachers assisted in this learning by applying practical knowledge from across the curriculum. Among the positive aspects from the qualitative data, regarding the teaching and learning resources, the participants stated that they can be able to refer what they have taught in the classroom to what students actually have seen in reality during the community tours. T1 described, “... with the signs on the street, it's easier to let students see what it actually looks like". Similarly T3 stated, "... now students can have a better idea and exact vision of map vs. space concept. With the map on hand, students now know when to turn right or left to where they are heading to"; T4 reported, "learning occurs in places on specific issues during the environmental discovery tour making content meaningful to students".

\subsubsection{Positive Connections from the Community Members}

On the other hand, in the qualitative section of interview, when community members were asked about what they liked about the collaborative community engagement activities in the work, their comments included (1) engagement, (2) joy to see children, (3) clear contribution to the school, (4) high frequency of communication, and (5) instant feedback from the children. Obviously, participants enjoyed working together with the school and sharing information with the children, see Figure 6 for pictures of learning activities beyond the classroom. For example, C2 commented, "I felt grateful seeing children learning something from us"; C3 indicated that "Those children were so adorable looking up the library books and learning how to check out library book", C4 stated that "looking at the children's big smiles on their face, I think I am just so cute too as a policeman". In addition, participants (C1, C3, C5) also reported that they were glad that they were able to make contribution to the education sector and appreciated for the opportunity to teach young children about the resources they have. For example, C2 said, "I've never imaged that I can teach children with my knowledge. Children now know about our occupation and get to know about the job duties. I feel like a school teacher too which was the dream when I was little. I feel good I can at least feel what it likes now. Thanks you for offering this great opportunity."; C4 mentioned, "one day tour teaching children about the police station is just so amazing. I did not know I can be part of resources enrich young kids with some knowledge". 

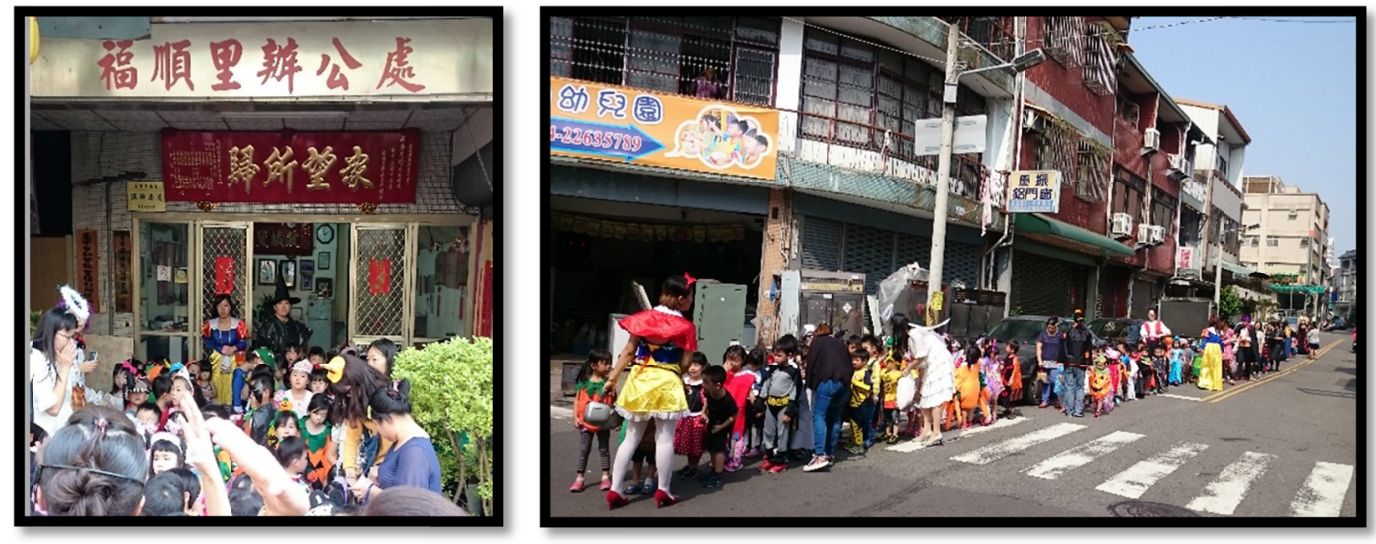

Figure 6. Sample Pictures of Curriculum Activities beyond the Classroom Wall

\subsection{Research Question 2: Participants' Negative Attitudes toward Active Community Engagement Collaboration}

\subsubsection{Negative Connections from the Teachers}

In contrast, when preschool teachers were invited to provide comments for what they disliked about the community engagement instruction, they listed a range of comments. These responses were therefore used as the qualitative data for determine the results of research question 2 in this study. Their comments included (1) much time spent on social, (2) time consuming on teaching hours, (3) traveling, and (4) students' safety concern. Some teachers (T5, T6) commented that one-day field-trip gave them hard time to adjust their daily teaching schedule, similarly, some teachers (T2, T3) reported that they spent too much time taking their students walking outdoor for environmental education projects. They continually stated that students did not really pay attention but fooling around with their peers when they were supposed to learn the environmental knowledge. While community resources gave teachers power to share information, they sometimes turn themselves from a helpful resource center to a time waster. Teacher 2 mentioned that she felt she spent too much time hanging outside on unnecessary conversation with her students during the community tours. Besides, T4 and T5 commented that they were so worried about their students' safety during the art craft activities at the park. Furthermore, regarding the safety concern, T4 complained that students went so wild and over excited at the parks and at the follower festivals; T6 was so afraid she would lose her students in public. Teachers who worried more about children's safety issue were the teachers of younger aged children, aged 4-5 children. Furthermore, it seems like teachers with younger aged children were more likely to worry about the safety issue when going to outdoor community events.

\subsubsection{Negative Connections from the Community Members}

In contrast, when asked about what community members dislike about the community engagement activities, their comments included (1) time spent on preparation, (2) difficult to schedule, and (3) lack of experience. Some community members commented collaborating with the school gave them extra work to prepare prior the school's visit. For example, C2 mentioned, "I have to spend a lot time for your visit. I need to prepare some work before you came while I already have tons of work to do"; C4 reported, "my boss even wanted me to clean up my desk to make it presentable for your visit"; C5 stated, "I spent so much time to prepare a presentation for your kids to know about our work place". Besides, $\mathrm{C} 1$ and $\mathrm{C} 2$ mentioned that they spent so much time to communicate with the school on scheduling a presentation to fit both the school and the community's schedule. Furthermore, some community members $(\mathrm{C} 2, \mathrm{C} 5)$ reported that they never had experience holding an event like this, and they felt a bit nervous prior the school's visit.

\subsection{Research Question 3: Decision to Continue Collaboration}

One closed-ended question was conducted at the end of interview process to determine the participants' final decision to whether to continue the community engagement collaboration or not. When asked about if this kind of collaboration should be continued in the near future, every of the participants $(100 \%)$ stated yes for the answers. 


\section{Conclusions}

The current research provided the participants perspectives of a community engagement instruction, proposing collaborative activities with the community. Collaboration between a school and its community is subject to continuing discussion. It has now a clear vision that both school and community benefit from the school-community collaboration. The overall results indicated that the participants agreed to continue establishing collaborative events in the near future and they saw positive impacts to the school, students, and the communities. The results of this study enlighten better understanding of management of resources (Sharan, Shachar, \& Levine, 1999). Early childhood teachers in this study believed that collaboration between the school and its community enhanced their teaching efficiency and also improved their students' comprehensive experience in the reality of settings. Teachers were delighted to see such positive results from implementing community activities into their instructions. Community members also felt grateful that they could be able to make contributions to the school and to the children themselves. The activities in this current study built a strong connection between the school and its community. Meanwhile, the communities were given opportunities for the public to share more information and resources with, which was a surprise bonus of this study.

Students' learning is an important objective that is brought to the forefront by educators as well as by community committees. Gray (1984) and Sergiovanni (1994) suggest that community involvements in schools enrich students' achievements and general learning environment which indeed contributes to a better teaching/learning setting for achievements. Most of the interviewees in this study addressed the positive learning impacts to the students. It therefore indicated that community engagement activities definitely brought advantages and positive achievements for the children. Their perception is supported by the previous studies (Gestwicki, 2013; Goodland, 1984; Wheeler, Gallagher, \& McDonough, 1995) that emphasize constructive roles of school-community partnership may contribute to better achievement. The results further indicated that community members may also contribute to school improvement. Indeed, the current study finally claims that school and community collaboration supports and enhances students' learning and school improvement, which provided positive support for a previous study (Buraphadeja \& Kumnuanta, 2011). Indeed, the school's reputation was getting higher and consequently a higher reputation attracted more new students to enroll, which was a surprise bonus from this study.

The strong connection between the collaboration with the community officials bring positive influences on in-school learning because it provides opportunities for students to interact with different professions. Students can take an interest in what professionals are doing, and interact with many kinds of local experts, such as policeman, fire fighter, members of public community, dentist, business owners, and artist among others. It can be very motivating both to students and teachers to have opportunities to share their working experience with others as recommended by Shulman (1997) and Wells (1999). The finding of this study could be also explained by the fact that learning is a social activity (Chen \& Bryer, 2012; Driver, Asoko, Leach, Mortimer \& Scott, 1994; Vygotsky, 1978; Wang, 2014). Integrating community activities into class curriculum may contribute to better learning in real world and share responsibilities in the teaching and learning process.

Evaluating the community engagement activities into instruction in early childhood curriculum in this study was undoubtedly useful, but complex. While some participants felt that connections between the school and its community was resourceful and joyful, some felt that this was very time consuming. The participants often mentioned that being part of the activities put them extra workload. If this issue is the primary reason for the working load, it can be solved easily and efficiently. The researchers would suggest the school head to arrange the duties to more instructional planners or assign more assistants prior the activities.

As a result of this study, community engagement activities in collaborative instruction appear to be valued by all children, school, and community. Results suggest that community engagement activities promotes a sociocultural constructivist learning environment that makes the need for newly acquired knowledge evidence and is perceived as being resourceful to the children. Teaching and developing learning is the process of developing the learner's knowledge (Caspi \& Reid, 2002). This is echoed by Ramsden (2003), who proclaims that "there is no such thing as learning in itself", since learning is "a change in the way we conceptualize the world around us" (p. 41). In this effort, collaboration between the school and its community may continue to be part of early childhood curriculum. Integrating community resources of all factors should be therefore approached systematically and raise awareness of active engagement in curriculum design. More importantly, the efforts should be made to raise awareness of community engagement and its benefits for child, the school, and the community as a whole. 


\section{References}

Airasian, P. W., \& Walsh, M. E. (1997). Constructivist cautions, Phi Delta Kappan, 78(6), 444-449.

ASA (1998). What Are Focus Groups? Pamphlet of American Statistical Association Series. Retrieved from https://www.scribd.com/document/76813247/05-03-ASA-Focus-Groups

Buraphadeja, V., \& Kumnuanta, J. (2011). Enhancing the sense of community and learning experience using self-pace instruction and peer tutoring in a computer-laboratory course. Australasia Journal of Education Technology, 27(8), 1338-1355. https://doi.org/10.14742/ajet.897

Caspi, J., \& Reid, W. (2002). Educational supervision in social work. NY: Columbia UP. https://doi.org/10.7312/casp10852

Chen, B., \& Bryer, T. (2012). Investigating instructional strategies for using social media in formal and informal learning. International Review of Research in Open \& Distance learning, 13(1), 87-104. https://doi.org/10.19173/irrodl.v13i1.1027

Crawford, B.A., Krajcik, J. S., \& Marx, R. W. (1999). Elements of a community of learners in a middle school $\begin{array}{lllll}\text { science } & \text { classroom. } & \text { Science } & \text { Education, } & \text { 83(6), }\end{array}$ https://doi.org/10.1002/(SICI)1098-237X(199911)83:6\%3C701::AID-SCE4\%3E3.0.CO;2-2

D’Angelo, C., Touchman, S., Clark, D., O’Donnell, A., Mayer, R., Dean, D. Jr., \& Hmelo-Silver, C. (2009). Constructivism. Retrieved from http:/www.education.com/reference/article/constructivism/

Driver, R., Asoko, H., Leach, J., Mortimer, E., \& Scott, P. (1994). Constructing scientific knowledge in classroom. Educational Researcher, 3(7), 5-12. https://doi.org/10.3102/0013189X023007005

Epstein, J. L. (2001). School, Family and Community partnerships: Preparing educators and improving schools. Colorado: Westview Press.

Fosnot, C. T. (2005). Constructivism: theory, perspectives, and practice. NY: Teachers College Press.

Fullan, M. (1997). The Challenge of school change: A collection of articles. IL: Skylight Training.

Gestwicki, C. (2013). Home, School \& Community Relations $\left(9^{\text {th }}\right.$ ed.). MA: Cengage Learning.

Goodland, J. I. (1984). A Place called school: Prospects for the future. NY: McGraw-Hill.

Kukla, A. (2000). Social constructivism and the philosophy of science. NY: Routledge.

Mallaguzzi, L. (1998). History, ideas and basic philosophy- An interview with Lella Gandini. In C. P. Edwards, L. Gandini, \& G. Forman (Eds.), The hundred languages of children- The Reggio Emilia Approach, Advanced Reflections (pp. 49-97). London: Ablex Publishing Corporation.

Ozturk, D. S. (2016). Is learning only a cognivite process? Or does it occur in a sociocultural environment?: "Constructivism" in the eyes of preschool teachers. Journal of Education and Training Studies, 4(4), 153-159. https://doi.org/10.11114/jets.v4i4.1268

Ramsden, P. (2003). Learning to teach in higher education ( $2^{\text {nd }}$ ed.). London: Routledge Falmer.

Sergiovanni, T. (1994). Building community in school. CA: Jossey-Bass.

Sharan, S., Shachar, H., \& Levine, T. (1999). The Innovative school organization and instruction. Westport: Bargin \& Garvey.

Shartrand, A. M., Weiss, H. B., \& Kreider, H. M., \& Lopez, M. E. (1997). New skills for new school: Preparing teachers in family involvement. MA: Harvard Family Research Project.

Shulman, L. (1997). Communities of learners and communities of teachers. Jerusalem: Mandel Institute.

Strauss, A., \& Corbin, J. (1998). Basics of qualitative research techniques and procedures for developing grounded theory ( $2^{\text {nd }}$ ed.). London: Sage.

Tal, R. T. (2001). Community-based science-technology education: A case study. Proceedings of the IOSTE Symposium in Southern Europe. ERIC Document ED 460860.

Vygotsky, L. S. (1978). Mind in Society: The development of higher psychological processes. MA: Harvard U.

--- . (1981). The instrumental method in psychology. In J. V. Wetsch, (Ed.), The Concept of activity in soviet psychology. NY: Shape. 
--- (1986). Thought and language. MA: MIT.

Wang, S. (2014). Collaboration factors and quality of learning experience on interactive mobile assisted social e-learning. The Turkish Online Journal of Educational Technology, 13(2), 24-34.

Wells, G. (1999). Dialogic inquiry: Towards a sociocultural practice and theory of education. Cambridge: Cambridge UP. https://doi.org/10.1017/CBO9780511605895

Wheeler, C., Gallagher, J. J., \& McDonough, M. (1995). Improving school community relations in Thailand: Social forestry, education and community participation. In P. Altbach \& W. Cummings (Eds.), The Asian educational challenge. New York: Sunny. 